\title{
PENERAPAN AUGMENTED REALITY PADA SERIOUS GAME EDUKASI PENYAKIT GIGI
}

\author{
Muhammad Faqih \\ Fakultas Teknik, Jurusan Teknik Informatika, Program Studi Informatika \\ Universitas Trunojoyo Madura \\ Email: muhammadfaqih0@gmail.com \\ Ari Kusumaningsih \\ Fakultas Teknik, Jurusan Teknik Informatika, Program Studi Informatika \\ Universitas Trunojoyo Madura \\ Email: ari.kusumaningsih@trunojoyo.ac.id \\ Arik Kurniawati \\ Fakultas Teknik, Jurusan Teknik Informatika, Program Studi Informatika \\ Universitas Trunojoyo Madura \\ Email: arik.kurniawati@trunojoyo.ac.id
}

\begin{abstract}
ABSTRAK
Pengalaman belajar yang menyenangkan akan menumbuhkan kemauan untuk terus belajar. Aplikasi pembelajaran multimedia interaktif merupakan sarana belajar mandiri yang menyenangkan. Penelitian ini bertujuan untuk membuat aplikasi pembelajaran multimedia interaktif, berupa pengenalan penyakit gigi, dengan memanfaatkan teknologi Augmented Reality (AR) serta serious mobile game, agar pengguna mendapatkan pengalaman belajar yang mengesankan. Penelitian ini menerapkan metode Interactive Multimedia System of Design and Development (IMSDD) yang terdiri dari System Requirement, Design Consideration, Implementation, dan Evaluation. Pada pengukuran User Experience (UX), digunakan 6 indikator, yaitu Importance, Interest, Valence, Playfulness, Impressed, dan Enjoy. Survey terhadap 20 responden diperoleh respon sangat positif dengan nilai indikator terbaik pada Impressed sebesar 2,9.
\end{abstract}

Kata Kunci: augmented reality; serious game; penyakit gigi.

\begin{abstract}
A pleasant learning experience will improve a willingness to continue learning. Interactive multimedia learning application is one of the fun self-learning tool. This study aims to create interactive multimedia learning applications, in the form of dental disease recognition, by utilizing Augmented Reality technology and serious mobile games, to get an impressive learning experience. This study applies the Interactive Multimedia System of Design and Development (IMSDD) method which consists of System Requirements, Design Consideration, Implementation, and Evaluation. User Experience measurement using 6 indicators, namely Importance, Interest, Valence, Playfulness, Impressed, and Enjoy. The survey of 20 respondents obtained a very positive response with the best indicator value on Impressed at 2.9.
\end{abstract}

Keywords: augmented reality; serious game; dental disease.

\section{PENDAHULUAN}

Kesadaran masyarakat Indonesia akan pentingnya kesehatan gigi terbilang masih cukup rendah. Berdasarkan data Riskesdas (Riset Kesehatan Dasar) pada tahun 2013 sebanyak kurang lebih 60 juta jiwa atau sebesar 25,9\% menderita penderita penyakit gigi dan mulut di Indonesia [1]. Dengan jumlah sebanyak itu, maka masih diperlukan banyak cara untuk meningkatkan kesadaran masyarakat dalam hal menjaga dan merawat kesehatan gigi. Salah satunya melalui media pembelajaran yang berfungsi untuk mengenalkan tentang penyakit gigi. Tentunya, saat ini banyak tersedia berbagai media pembelajaran, salah satunya adalah Multimedia Pembelajaran Interaktif, yakni media pembelajaran yang merupakan gabungan dari berbagai media yang dirangkai secara terpadu dan interaktif untuk menyampaikan pesan yang terkait dengan pembelajaran tertentu [2]. Pengunaan smartphone dalam beberapa tahun terakhir juga sangat mendukung 
media pembelajaran multimedia dengan beberapa keuntungan yang dimiliki oleh smartphone seperti mobile, interaktif sehingga pengguna merasa senang terhadapat aplikasi pembelajaran yang disuguhkan [3]. Dalam menunjang multimedia interaktif, salah satu teknologi yang sangat bermanfaat dalam pembelajaran adalah Augmented Reality(AR), penggunaan teknologi AR juga berkembang pesat dalam menunjang pembelajaran dalam dua dekade terakhir [4] dari sisi penggunaan, manfaat, fitur dan keefektifan. Penelitian ini akan membahas tentang tahapan dalam membuat aplikasi berbasis mobile untuk pengenalan penyakit gigi beserta pengukuran kebermanfaatannya aplikasi ini terhadap pengguna.

\section{METODOLOGI PENELITIAN}

Metodologi penelitian yang digunakan untuk membangun aplikasi ini adalah Interactive Multimedia System of Design and Development (IMSDD). Tahapan dalam IMSDD ada 4 tahap [5], yaitu ;

a. Mendefinisikan Kebutuhan Sistem (System Requirement), tahapan ini meliputi mendefinisikan sistem dan menentukan siapa pengguna dari sistem tersebut.

b. Perancangan (Design Consideration), menggambarkan secara jelas detail desain, dalam bentuk :

1) Deskripsi Aplikasi

2) Flowchart

3) Mockup Aplikasi

c. Implementasi (Implementation), mengimplementasi dari perancangan sebelumnya menjadi aplikasi prototype dan dilakukan pengujian (tes beta) terhadap aplikasi.

d. Evaluasi (Evaluation), mengevaluasi hasil pekerjaan kepada target pengguna ysng telah ditentukan untuk mendapatkan hasil dari sistem yang teah dibuat.

\section{MENDEFINISIKAN KEBUTUHAN SISTEM}

Aplikasi ini ditujukan untuk semua orang tidak ada batasan usia. Aplikasi ini menggunakan AR sebagai media pembelajaran untuk pengenalan penyakit gigi berbasis game. Media pembelajaran yang dibangun adalah aplikasi mobile yang dijalankan pada smartphone berbasis android. Penyakit gigi yang digunakan dalam aplikasi ini adalah Gigi Karies, Gigi berlubang, dan Radang Gusi. Dalam penggunaan Augmented Reality juga diperlukan marker sebagai penanda. Marker yang digunakan dalam penelitian ini adalah marker based tracking. Aplikasi ini berbasis Serious Game, yang fungsi utama adalah tidak hanya sekedar bermain game, melainkan lebih ke sisi edukasi.

Rumusan masalah yang ada dalam penelitian ini adalah untuk mengetahui seberapa efektif aplikasi Augmented Reality yang dibuat dalam mengenalkan penyakit gigi dengan menggunakan metode Uji User Experience Measurement dan dengan perhitungan Skala Likert untuk mengetahui tingkat kepuasan pengguna dalam penggunaan aplikasi.

\section{PERANCANGAN}

\subsection{Deskripsi Aplikasi}

Aplikasi ini merupakan sebuah aplikasi edukasi yang bertujuan untuk mengenalkan penyakit gigi. Dengan menggunakan teknologi Augmented Reality menjadikan aplikasi ini menjadi lebih menarik. Dalam aplikasi ini terdiri dari 4 halaman utama, yaitu: Halaman awal, halaman scan marker, halaman materi, dan halaman kuis.

\subsection{Flowchart Aplikasi}

Flowchart atau diagram alir bertujuan untuk memudahkan pemahaman tentang alur sistem. Flowchart aplikasi dapat dilihat pada gambar 1 .

\subsection{Mockup Aplikasi}

Mockup aplikasi berisi rancangan desain interface aplikasi yang akan dibuat. Mockup dibuat dalam beberapa tampilan, seperti dapat dilihat pada gambar 2 . 


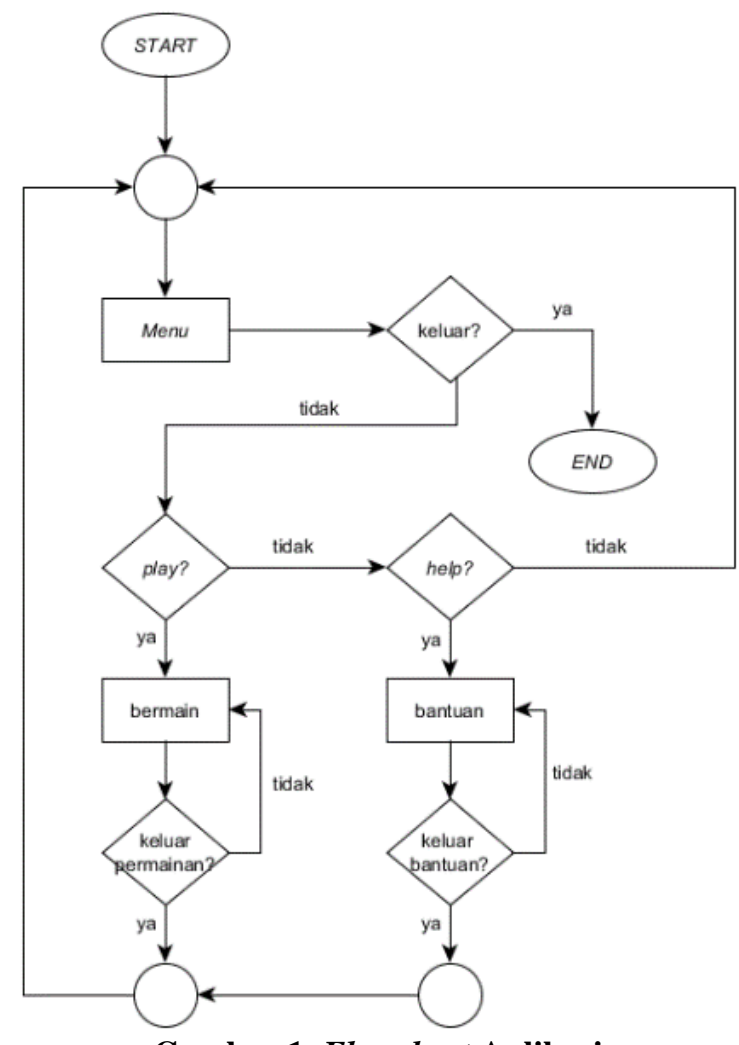

Gambar 1. Flowchart Aplikasi

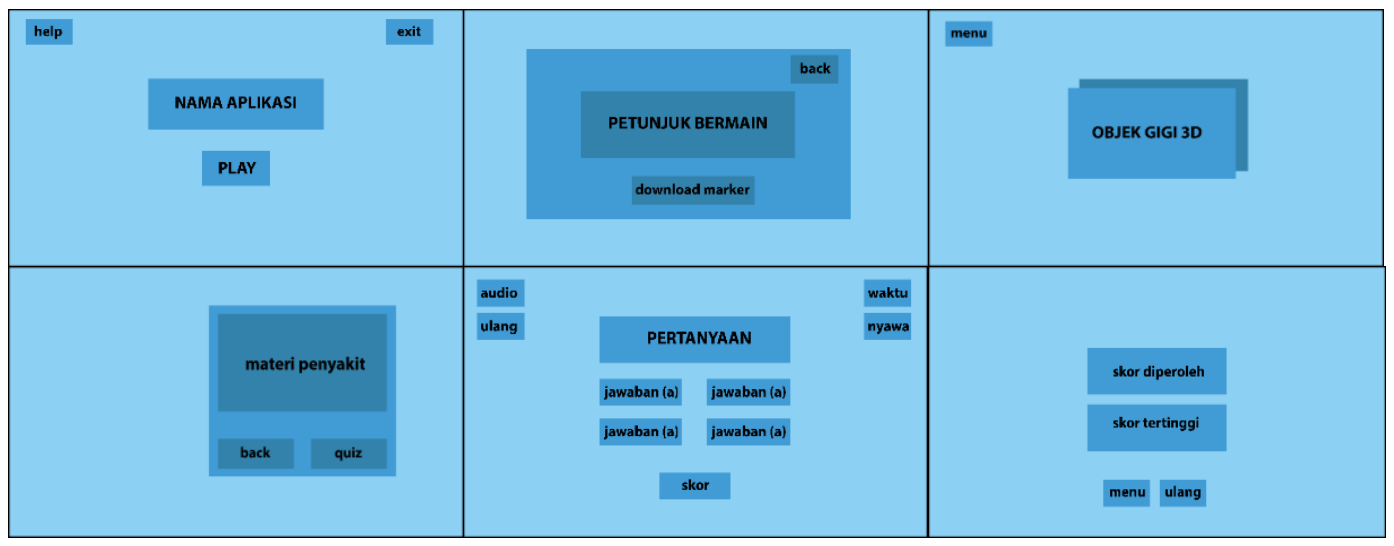

Gambar 2. Mockup Aplikasi

\section{IMPLEMENTASI SISTEM}

Tahap implementasi adalah pengembangan dari tahap perancangan yang sudah dibuat. Pada tahap ini dilakukan penerapan sistem ke dalam aplikasi sesungguhnya dan pada tahap ini juga dilakukan uji coba terhadap aplikasi untuk mengetahui apakah aplikasi sudah sesuai dengan tujuan atau tidak. Aplikasi ini dibangun menggunakan beberapa perangkat lunak seperti : Adobe Illustrator, digunakan untuk membuat objek 2D, kebutuhan aset aplikasi, Blender digunakan untuk membuat dan mengedit objek 3D dan Unity digunakan untuk membangun aplikasi ini. Beberapa tahapan yang dilakukan antara lain : pembuatan objek 2d, objek 3d, pembuatan marker dan pengembangan aplikasi dengan Unity.

\subsection{Pembuatan Objek 2D}

Objek 2D digunakan sebagai aset untuk keperluan user interface, objek dibuat menggunakan aplikasi Adobe Illustrator. Objek-objek 2D yang dibuat serta fungsinya dapat dilihat dalam tabel 1 . 
Tabel 1. Aset dan kebutuhan

Fungsi
Menampilkan instruksi singkat cara
pengunaan aplikasi
Kembali ke menu utama
Menyalakan dan menonaktifkan
audio
Bengulangi sesi kuis
Background aplikasi.
Background menang kuis

\subsection{Pembuatan Objek 3D}

Pada tahap ini dibuat objek gigi dalam bentuk 3D. Objek gigi 3D dibuat menggunakan aplikasi Blender. Objek penyakit gigi juga dibuat pada tahap ini. Objek gigi 3D yang sudah dibuat dapat dilihat pada gambar 3 .

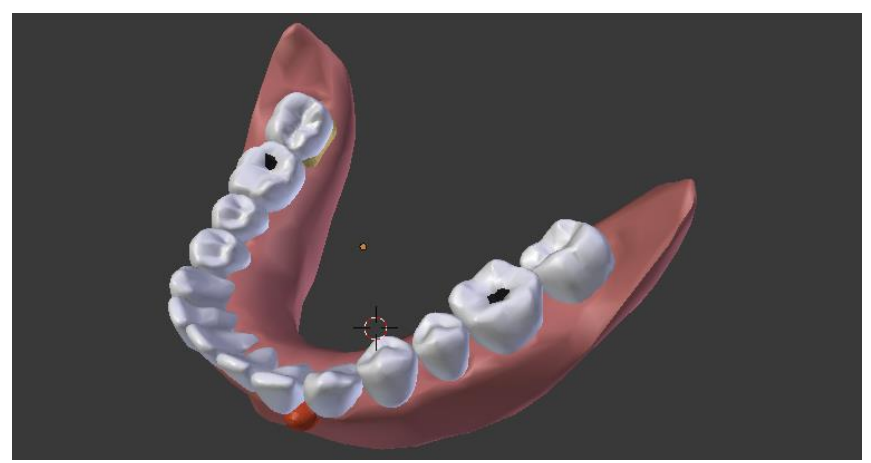

Gambar 3. Objek Gigi 3D

\subsection{Pendaftaran Lisensi Marker ke Vuforia}

Untuk dapat menggunakan marker diperlukan sebuah kode lisensi yang dapat diperoleh dari website Vuforia. Masuk ke https://developer.vuforia.com/ kemudian daftarkan marker untuk memperoleh lisensi. 
Berikut contoh lisensi Vuforia dapat dilihat pada gambar 4 dan gambar marker yang digunakan dalam penelitian ini dapat dilihat pada gambar 5 .

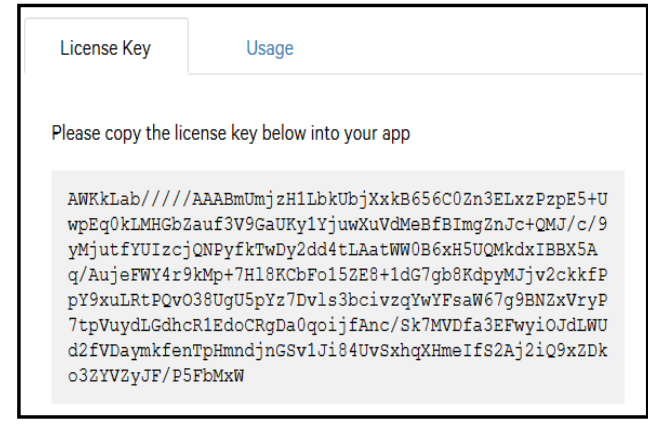

Gambar 4. Contoh Lisensi Vuforia

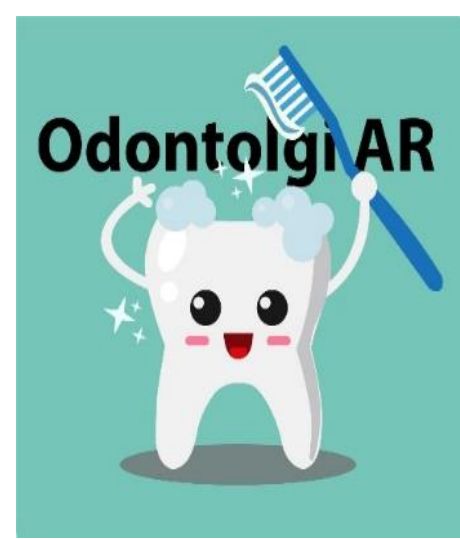

Gambar 5. Contoh Gambar Marker

\subsection{Pembuatan Aplikasi pada Unity}

Pada tahap ini dilakukan proses pembuatan aplikasi seperti penyesuaian tampilan, memasukkan aset, memasukkan materi, menambahkan audio, pemberian skor, dengan menggunakan aplikasi Unity. Pada langkah ini aplikasi juga dibuat kedalam bentuk (.apk) sehingga dapat dijalankan di perangkat Android. Gambar 6 Berikut adalah aplikasi yang telah dibuat.

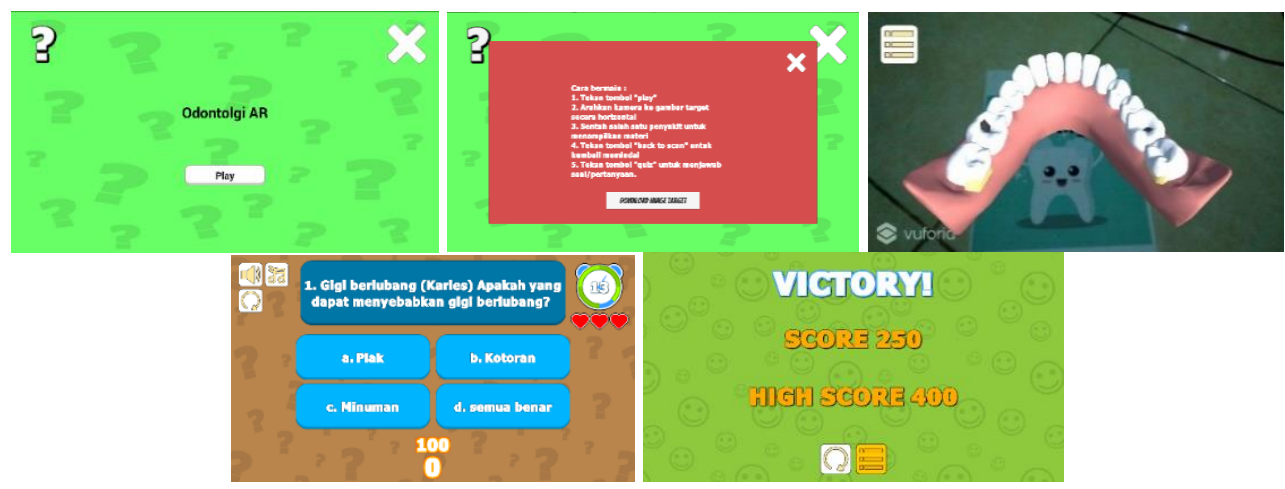

Gambar 6. Aplikasi AR Gigi

\subsection{Script pada Aplikasi}

Berikut beberapa script atau listing program yang digunakan saat membuat aplikasi: 
1. Script Button Play

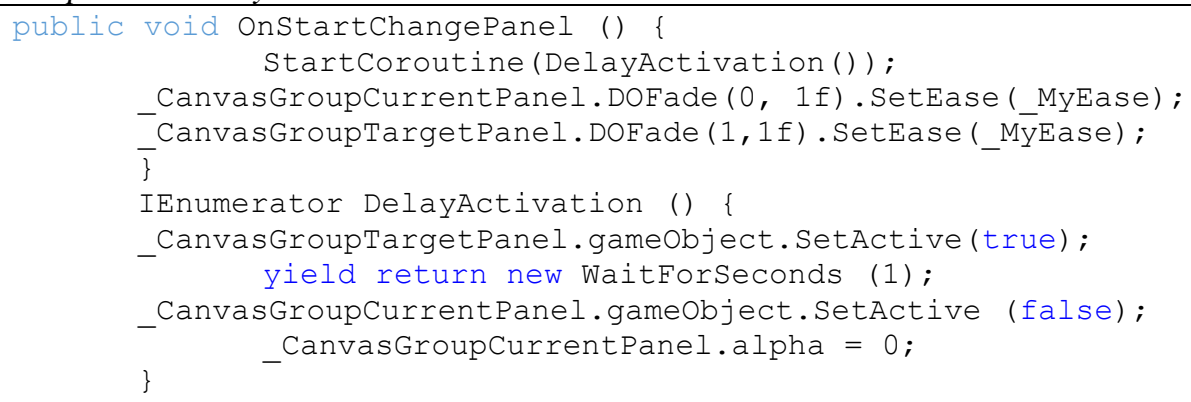

2. Script Button Help

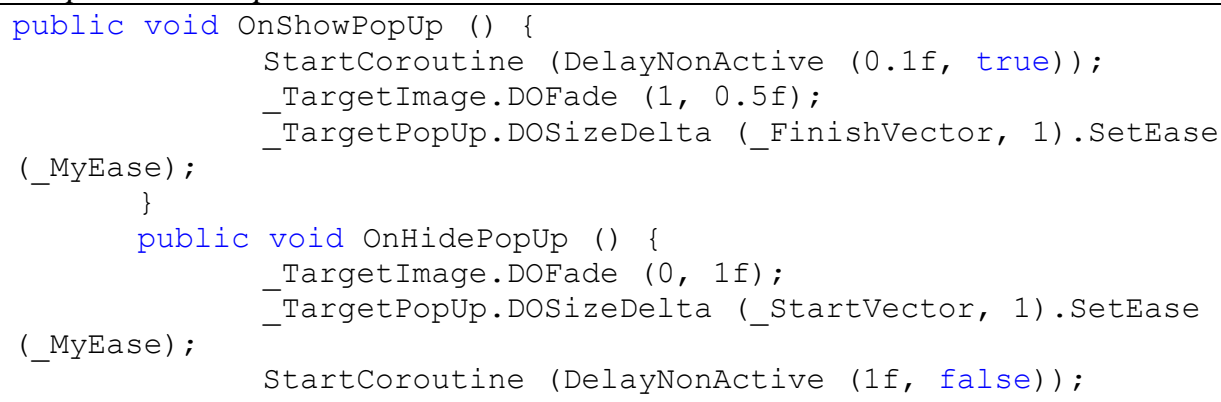

3. Script Button Exit

public void Quit()

Application.Quit () ;

\section{Script Back to Scan}

public void SetON (Gameobject GO) \{

GO. SetActive (true);

5. Script Quiz

public void changescene(string scene)

Application. LoadLevel (scene);

6. Script saat Menyentuh Objek Gigi

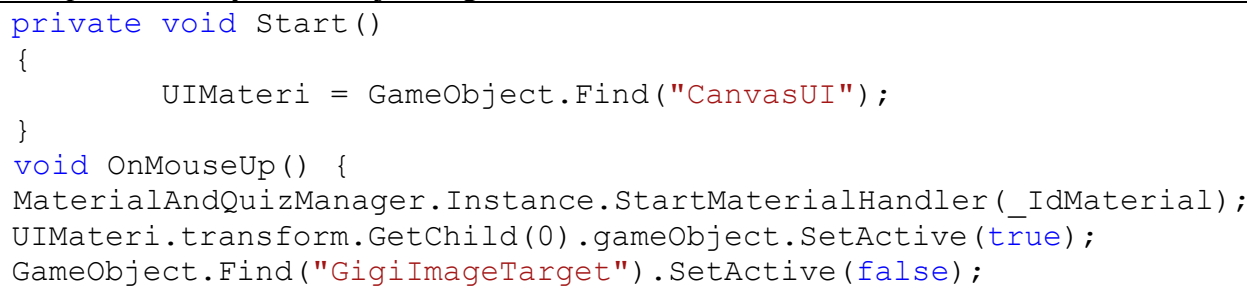

7. Script Button Audio

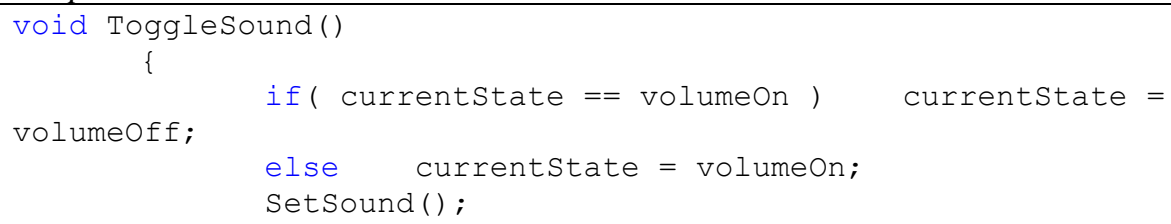




\section{Script Button Restart}

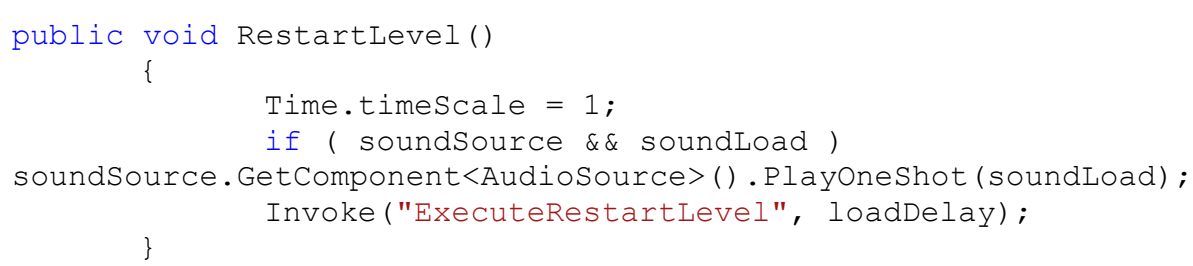

9. Script Button Answer

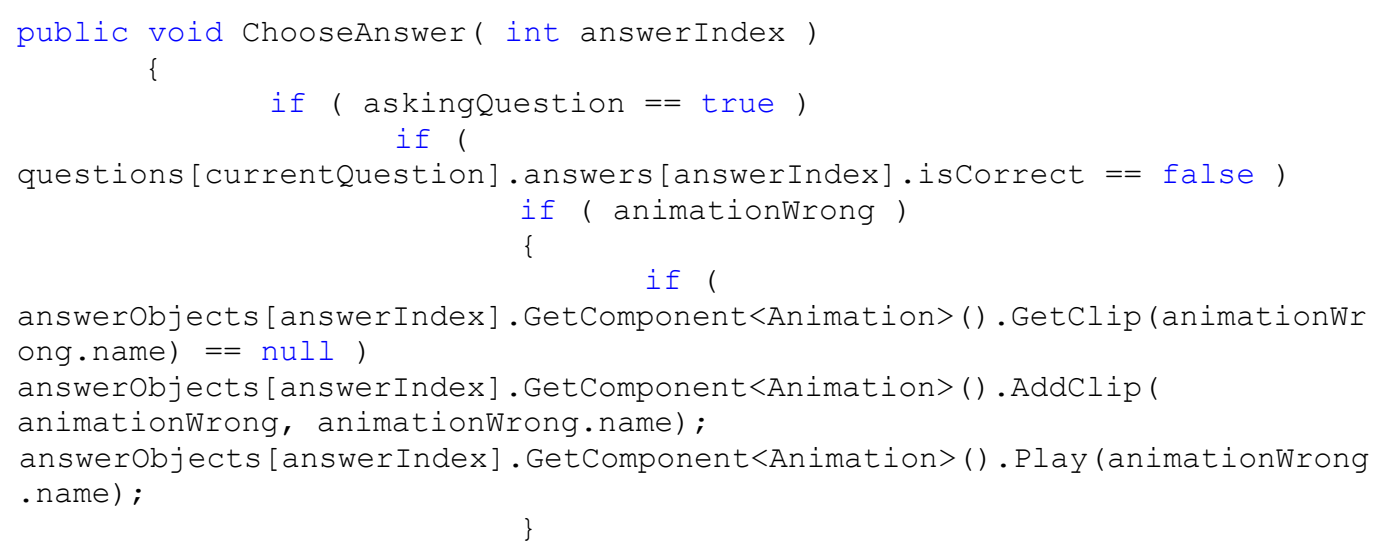

\section{HASIL UJI APLIKASI}

Uji aplikasi menggunakan metode User Experience Measurement, dan untuk mengetahui hasil uji aplikasi menggunakan perhitungan metode Skala Likert. User Experience Measurement adalah sebuah metode yang digunakan untuk mengetahui bagian apa yang mempengaruhi pengalaman pengguna, seperti emosi dan perasaan pengguna ketika berinteraksi dengan aplikasi [6]. Terdapat 15 poin indikator yang ada dalam User Experience Measurement, yaitu: Role Engagement, Attention, Interest, Importance, Copresence, Interaction, Arousal, Physical Presence, Valence, Impressed, Competence, Challange, Enjoy, Playfulness, dan Control. Namun dalam penelitian ini diambil 6 poin indikator yang disesuaikan dengan objek yang diteliti. Poin indikator yang dipilih dapat dilihat dalam tabel 2.

Tabel 2. Indikator user experience yang digunakan dalam penelitian

\begin{tabular}{ccc}
\hline Nama Indikator & Deskripsi & Komponen Psikologi \\
\hline Importance & Pemahaman terhadap isi aplikasi & Motivasi Koginitif \\
Interest & Aplikasinya menarik & Motivasi Emosi \\
Valence & Senang, tidak bosan atau cemas dengan aplikasinya & Emosi \\
Playfulness & Mudah menggunakan aplikasi, jelas, kreatif, imajinatif & Daya perasaan \\
Impressed & Terkesan dengan aplikasi terhadap fitur maupun & Daya perasaan \\
Enjoy & tampilan & Daya perasaan \\
\hline
\end{tabular}

Skala Likert adalah skala yang secara umum digunakan untuk mengukur sikap seseorang/responden terhadap suatu pernyataan [7]. Dalam Skala Likert untuk mengukur sikap responden, digunakan beberapa pernyataan dengan menunjuk pilihan pada setiap pernyataan, baik untuk pernyataan positif ataupun negatif , masing-masing pernyataaan memiliki nilai yang dapat dilihat dalam tabel 3 [8]. Pernyataan negatif yang penilaiannnya merupakan kebalikan dari pernyataan positif [9]. 
Tabel 3. Bobot penilaian skala likert untuk pernyataan positif dan negatif [8]

\begin{tabular}{cc}
\hline Pernyataan Positif & Skor Positif \\
\hline Sangat Setuju & 5 \\
Setuju & 4 \\
Biasa Saja & 3 \\
Tidak Setuju & 2 \\
Sangat Tidak Setuju & 1 \\
\hline
\end{tabular}

\begin{tabular}{cc}
\hline Pernyataan Negatif & Skor Positif \\
\hline Setuju & 3 \\
Biasa Saja & 2 \\
Tidak Setuju & 1 \\
\hline
\end{tabular}

Berikut formulasi yang digunakan untuk menentukan kuartil 1, median, dan kuartil 3 pada Skala Likert, sebelum mendapatkan skor total untuk mengetahui sikap responden terhadap aplikasi. Persamaan untuk mendapatkan skor terendah dari responden

$$
C_{\min }=S_{\min } * N_{2}
$$

Persamaan mendapatkan skor tertinggi dari responden

$$
C_{\max }=S_{\max } * N_{2}
$$

Persamaan mendapatkan jumlah keseluruhan skor terendah dari responden

$Z_{\min }=C_{\min } * N_{1}$

Persamaan mendapatkan Jumlah keseluruhan skor tertinggi dari responden

$Z_{\max }=C_{\max } * N_{1}$

Persamaan menentukan median :

$M_{e}=\frac{Z_{\min +} Z_{\max }}{2}$

Persamaan menentukan kuartil 1:

$Q_{i 1}=\frac{Z_{\min +M_{e}}}{2}$

Persamaan menentukan kuartil 3:

$Q_{i 3}=\frac{Z_{\max }+M_{e}}{2}$

Keterangan :

$N_{1}=$ Jumlah Responden

$N_{2}=$ Jumlah Pertanyaan

$S_{\text {min }}=$ Bobot nilai terendah

$S_{\max }=$ Bobot nilai tertinggi

$C_{\text {min }}=$ Skor terendah

$C_{\text {max }}=$ Skor tertinggi

$Z_{\min }=$ Jumlah keseluruhan skor terendah

$Z_{\max }=$ Jumlah keseluruhan skor tertinggi

$M_{e}=$ Median

$Q_{i 1}=$ Kuartil 1

$Q_{i 3}=$ Kuartil 3

Uji aplikasi dilakukan kepada 20 responden dari kalangan usia mulai 8-29 tahun. Responden diberikan lembar pernyataan kuisioner berdasarkan 6 poin indikator yang dibagi menjadi pernyataan positif dan 
negatif. Dengan menggunakan persamaan (1)-(7), diperoleh hasil perhitungan dari data kuisioner 20 responden adalah sebagai berikut:

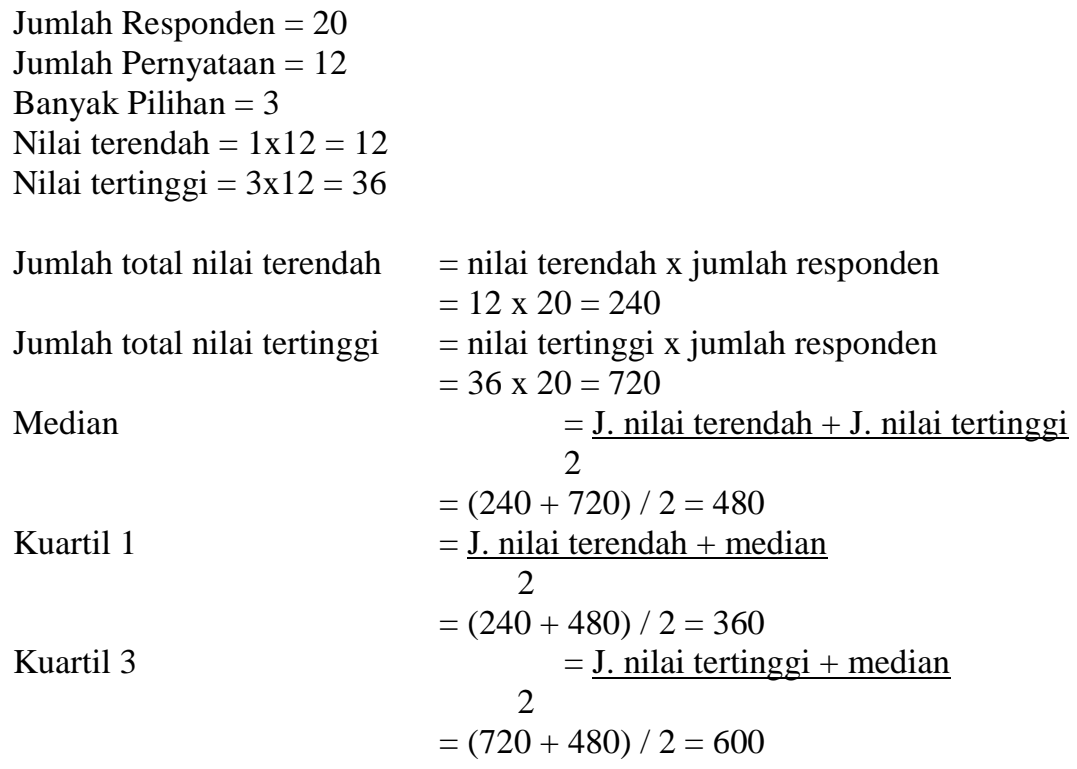

Kuartil 1

Kuartil 3

$$
=\underline{\mathrm{J} \text {. nilai tertinggi }+ \text { median }}
$$$$
=(720+480) / 2=600
$$

Untuk pengujian aplikasi, maka beberapa pertanyaan yang harus dijawab oleh responden adalah sebagaimana yang terdapat pada tabel 4 .

Tabel 4. Desain pertanyaan yang diajukan kepada responden

\begin{tabular}{|c|c|c|}
\hline \multirow[t]{2}{*}{ Indikator } & \multicolumn{2}{|c|}{ Pernyataan } \\
\hline & Positif & Negatif \\
\hline Importance & Saya dapat memahami materi dalam aplikasi & $\begin{array}{l}\text { Saya tidak dapat memahami materi } \\
\text { dalam aplikasi }\end{array}$ \\
\hline Interest & $\begin{array}{l}\text { Saya tertarik dengan aplikasi edukasi seperti } \\
\text { ini }\end{array}$ & $\begin{array}{l}\text { Saya tidak tertarik dengan aplikasi } \\
\text { edukasi seperti ini }\end{array}$ \\
\hline Valence & $\begin{array}{l}\text { Aplikasi ini menyenangkan dan tidak } \\
\text { membosankan }\end{array}$ & $\begin{array}{l}\text { Aplikasi ini tidak menyenangkan dan } \\
\text { tidak membosankan }\end{array}$ \\
\hline Playfulness & $\begin{array}{l}\text { Aplikasi dapat dengan mudah digunakan, } \\
\text { jelas, kreatif dan imajinatif }\end{array}$ & $\begin{array}{l}\text { Aplikasi tidak mudah digunakan, } \\
\text { jelas, kreatif dan imajinatif }\end{array}$ \\
\hline Impressed & Saya terkesan dengan tampilan gigi $3 \mathrm{~d}$ & $\begin{array}{l}\text { Saya tidak terkesan dengan tampilan } \\
\text { gigi } 3 d\end{array}$ \\
\hline Enjoy & Aplikasi ini bermanfaat & Aplikasi ini tidak bermanfaat \\
\hline
\end{tabular}

Dari kuisioner, diperoleh hasil total nilai dari 20 responden dengan menggunakan Skala Likert (gambar 7) sebesar 677, yang artinya aplikasi ini bernilai positif bagi pengguna.

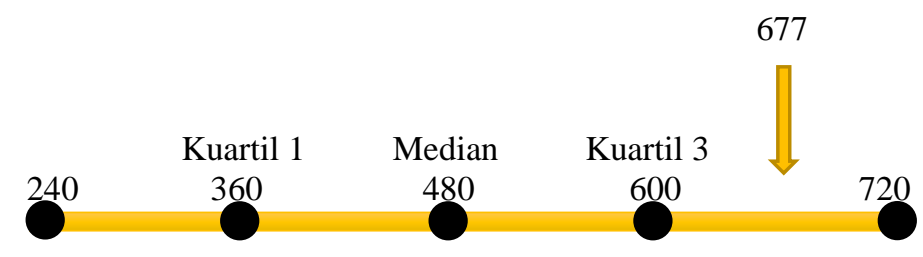

Gambar 7. Aplikasi AR Gigi

Dengan nilai untuk masing-masing indikator user experience seperti yang terlihat dalam tabel 5, dapat dilihat beberapa poin indikator dengan nilai tertinggi yaitu Interest dengan nilai 2,85, Playfulness dengan nilai 2,875, dan Impressed dengan nilai 2,9. Sehingga dapat disimpulkan bahwa daya tarik, kemudahan, serta perasaan senang saat bermain aplikasi menjadi indikator positif bagi responden. 
Tabel 5. Hasil nilai masing-masing indikator

\begin{tabular}{cc}
\hline Indikator & Skor \\
\hline Importance & 2,775 \\
Interest & 2,85 \\
Valence & 2,775 \\
Playfulness & 2,875 \\
Impressed & 2,9 \\
Enjoy & 2,75 \\
\hline
\end{tabular}

\section{KESIMPULAN}

Dari hasil uji coba yang telah dilakukan, terdapat kesimpulan yang dapat diambil yaitu:

a. Aplikasi Augmented Reality pada Serious Game Edukasi Penyakit Gigi sangat efektif dalam menyampaikan materi penyakit gigi kepada pengguna. Hal ini dapat dilihat dari nilai indikator importance (yang berarti pemahaman terhadap isi aplikasi) dimana 17 dari 20 responden atau sebesar 85 persen responden yang mengisi kuisioner menyatakan setuju/paham terhadap materi dalam aplikasi.

b. Dari hasil perhitungan dengan Skala Likert, diperoleh nilai keseluruhan dari 20 responden adalah sebesar 677. Nilai ini berada diantara nilai Kuartil 3 (dengan nilai 600) dan jumlah total nilai tertinggi (dengan nilai 720). Nilai yang berada pada posisi ini berarti menyatakan bahwa respon pengguna terhadap aplikasi adalah sangat positif.

c. Nilai indikator terbaik terdapat pada indikator impressed sebesar 2,9.

\section{DAFTAR PUSTAKA}

[1] Trihono, 2013. Riset Kesehatan Dasar. Badan Penelitian dan Pengembangan Kesehatan Kementrian Kesehatan RI.

[2] Miarso, Y, 2011. Menyemai Benih Teknologi Pendidikan. Prenada Media Group

[3] Chachila, K., Engkamatb, A., Sarkawic, A., Shuibd A. R. A., 2015 ."Interactive Multimedia-based Mobile Application for Learning Iban Language (I-MMAPS for Learning Iban Language)”, Procedia - Social and Behavioral Sciences 167267 - 273

[4] Chen, P., Liu, X., Cheng, W., Huang, R., 2016. "A review of using Augmented Reality in Education from 2011 to 2016", Innovations in Smart Learning, Lecture Notes in Educational Technology

[5] Dastbaz, M., 2003. Designing Interactive Multimedia System, New York : McGraw-Hill Company

[6] Takatalo, J., Häkkinenb, J., Kaistinena, J., Nymana, G., 2007. "Measuring User Experience in Digital Gaming: Theoretical and Methodological Issues", Proceedings of SPIE - The International Society for Optical Engineering 6494

[7] Risnita, 2012. "Pengembangan skala model likert", Edu-Bio Vol. 3, Tahun 2012

[8] Budiaji, W., 2013. "Skala Pengukuran dan Jumlah Respon Skala Likert", Jurnal ilmu pertanian dan perikanan, vol. 2, no. 2, pp. 127-133.

[9] A. Kusumaningsih, A. Kurniawati, C. V. Angkoso, E. M. Yuniarno, and M. Hariadi, "User experience measurement on virtual dressing room of Madura batik clothes," Proceedings - 2017 International Conference on Sustainable Information Engineering and Technology, SIET 2017, vol. 2018-January, pp. 203-208, 2018. 